\title{
Próceres campesinos en la guerra de la Independencia del Perú
}

\section{RESUMEN}

En el presente artículo se presentan los resultados de una investigación bibliográfica sobre la participación de los campesinos en la guerra por la Independencia del Perú. Considerando la importancia de volver a estudiar y reflexionar sobre el carácter social de este proceso que, como la Conquista hispana y la Guerra de Chile contra el Perú, han marcado hitos trascendentales en nuestra historia. Se presentan dos de las cuatro etapas de esta guerra independendista, las que se inscriben entre 1816 y 1824 , en ellas en forma transversal se ha considerado la participación y los hechos de la gente del pueblo, de campesinos y campesinas que integraron las partidas, las montoneras, las guerrillas y el mismo ejército patriota. Un número altísimo de ellos y ellas ofrendaron sus vidas en aras de la independencia aunque al final los ofrecimientos de los criollos triunfadores no se cumplieron.

Palabras Clave: montoneras; campesinos; patriotas; proclama de Independencia.

\section{Próceres campesinos in the war of the Independence of Peru}

\begin{abstract}
In the present article the results of a bibliographical investigation on the participation of the peasants in the War for the Independence of Peru are presented. Considering the importance of returning to study and reflect on the social nature of this process, which, like the Spanish Conquest and the Chilean War against Peru, have marked transcendental milestones in our history. Two of the four stages of this independence war are presented, those that register between 1816 and 1824, in them in a transversal way the participation and facts of the people of the town, of peasants and peasants, that integrated the parties, the montoneras, the guerrillas and the same patriot army. A very high number of them and they offered their lives for the sake of independence but in the end the offerings of the triumphant criollos were not fulfilled.
\end{abstract}

KeYwords: Montoneras; Peasants; Patriots; Proclamation of Independence. 
La independencia no empezó con San Martín y Bolívar. No empezó con la ayuda exterior de argentinos, chilenos y colombianos. La independencia peruana fue un largo proceso. Comenzó el día siguiente de la derrota del Inca por Pizarro. Pablo Macera (1985: 6)

\section{Introducción}

$\mathbf{P}$ ara los peruanos volver a estudiar la historia del Perú es una necesidad permanente, especialmente para quienes están vinculados a las ciencias sociales y humanidades, pues no podemos seguir creyendo y repitiendo la historia oficial que relieva las acciones de los que se aprovecharon de los inmensos recursos que dispone nuestro país, así como se apoderaron del poder político y económico, y olvidan que fueron los hombres y mujeres del pueblo los que con su decidida participación nos dieron la patria que hoy tenemos, que los historiadores oficiales u oficiosos no sólo la han olvidado sino que la han tergiversado.

Tres son los momentos decisivos que marcaron el rumbo de nuestra historia patria, la Conquista hispana, la Guerra por la Independencia y la Guerra de Chile contra el Perú. La primera marcó el rumbo actual, destruyó la economía inca y con ello su organización social, sus instituciones, su mundo cultural e ideológico; impusieron su organización económica basada en la explotación minera, introdujeron plantas y animales no conocidos por los antiguos peruanos, sometieron a los nativos a la servidumbre en las encomiendas, haciendas, estancias, obrajes y minas; también en la reducciones de indígenas y en el común de indios. Desplazaron sus creencias religiosas y divinidades con las cruces, los santos, las vírgenes y cristos que trajeron, para ello desplegaron un fuerte trabajo evangélico, extirparon las idolatrías, aplicaron los acuerdos de los Concilios Limenses a través de la Inquisición, impusieron su régimen político con el virrey, los corregidores, los oidores y otros, así como implantaron las Capitanías, Intendencias y Partidos. No podemos dejar de mencionar que trajeron a los esclavos negros y con ellos el rico mestizaje que hoy tenemos.

La Guerra por la Independencia fue un largo proceso en la que contendieron distintas fuerzas, las principales: la realista absolutista versus la patriota liberal y separatista, cada una con diferentes actores. A ella se sumaron las fuerzas americanas que llegaron desde el sur y el norte con San Martín y Bolívar; con ellas monitoreándolas, el colonialismo británico ambicioso por desplazar a España de sus dominios americanos. En el presente trabajo veremos fundamentalmente la participación precursora de los campesinos en este largo proceso.

Para desarrollar el tema sobre la participación de los próceres campesinos en la Guerra por la Independencia, se ha considerado hasta donde el tiempo y las fuentes permiten, a los que vivían en el común de indios y comunidades del área andina, pobladores del área rural que trabajaban y vivían de la agricultura, la ganadería, del trabajo minero y el comercio, actividades con un nivel de desarrollo extensivo. Su condición social era de campesinos libres, campesinos siervos, negros esclavos y libertos, pequeños comerciantes, sacerdotes doctrineros. Sin dejar de mencionar a patriotas de sectores pudientes. Su condición étnica era de indios, mestizos, negros y algunos criollos blancos; su situación económica en general era de los sectores medios bajos, pobres y muy pobres.

Su identificación con la causa patriota fue todo un proceso, desde el comienzo fueron convocados o reclutados por uno u otro bando; se cambiaban según su convicción o la fuerza que se le imponía, o el de sus intereses personales y las condiciones familiares en las que vivían. En estas circunstancias se vio que conforme participaban en más rebeliones contra la corona hispana y cuanto mayor represión, tributos, mitas, diezmos, repartimientos mercantiles se imponían contra las poblaciones de indígenas, estas fueron sumando a la causa patriota que fue ganando espacio en su sentir, aprovechado por los criollos blancos y acomodados que con las ideas de la ilustración europea, las proyecciones de la Revolución francesa y de la Independencia norteamericana, pudieron hacer del movimiento una guerra por la Independencia a su favor, que resguardase sus intereses económicos y los mantenga en el nuevo poder a instaurarse.

Se considera la participación de los campesinos en el ejército patriota integrando partidas, montoneras y guerrillas, modalidad de organización que más se adaptaba a sus acciones bélicas, por el escaso armamento y municiones, por su formación militar elemental o sin ella, por falta de recursos económicos, por la difícil orografía que la conocían a la perfección 


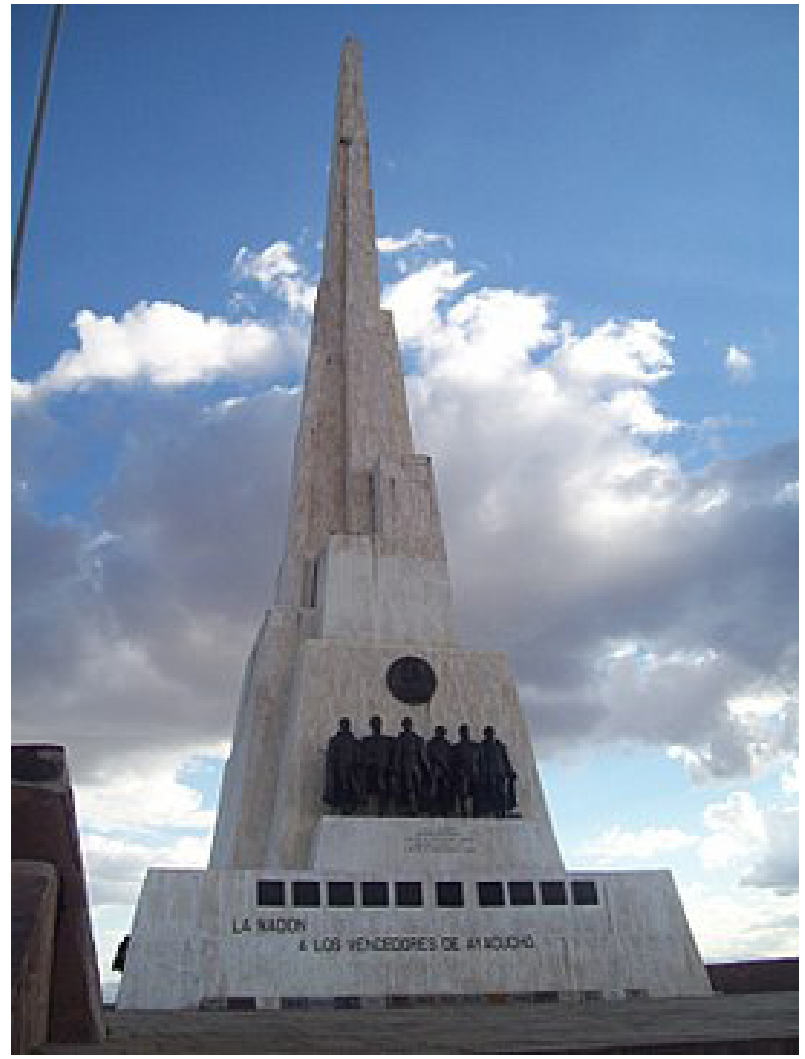

Santuario histórico de la Batalla de Ayacucho

y para poder golpear al enemigo sobre todo en los desfiladeros, en las abras, mantener informados a sus jefes de los movimientos realistas así sean descubiertos y morir por la causa de la revolución libertadora. Igualmente se señalan los lugares del territorio en los cuales se desenvolvieron fundamentalmente las acciones bélicas, sea en la ceja de selva, en el sur andino, en el norte y particularmente en el centro del Perú.

De acuerdo con los estudios consultados, en el proceso de la Guerra por la Independencia se distinguen cuatro etapas: la que se desarrolla antes de la rebelión de Túpac Amaru II (1780). La segunda, entre 1780 y 1816 , de los movimientos precursores y el gobierno de Abascal; la tercera, entre 1816 y 1821, de la declaración de la Independencia; la cuarta, de 1822 a 1824, del Congreso Constituyente a la Batalla de Ayacucho. En el presente artículo se expondrán las dos últimas. En cada una de estas etapas, al lado del despliegue de los ejércitos que lucharon por la expulsión de los colonialistas españoles, estaban las masas campesinas convertidas en indispensables para el triunfo final. Se procura brindar al pueblo peruano, una visión ajustada a la verdad histórica.

\section{Los campesinos y montoneros en la Independencia, 1816-1821}

\section{Fuerzas en conflicto: patriotas y realistas}

Las distintas fuerzas y sectores fueron convergiendo al momento decisivo de la independencia, la contradicción principal estaba entre la monarquía española y los patriotas que luchaban por la independencia. La Corona hispana fortalecida por la expulsión de los franceses de su territorio y la presencia de virreyes como Abascal que asumió la defensa obstinada del colonialismo de estilo borbónico y, por otro lado, los patriotas sudamericanos y peruanos en particular, apoyados por las corrientes libertarias de San Martín y Bolívar, con anuencia de los británicos. Puede observarse los variados intereses en juego de cada una de estas fuerzas y, de manera especial el dominio del territorio peruano, de sus inmensos recursos naturales, de su abundantísima fuerza laboral, de los mercados, de los derechos civiles, de la libertad, la fraternidad y la autonomía de los pueblos.

Como se comprenderá la misión no fue nada sencilla, no era fácil, había que concentrar muchas voluntades e intereses, especialmente para el bando patriota. Fue obra de hombres con la altura de héroes que pudieron llevar con éxito esta gesta libertadora. En nuestro caso se necesitaba la coordinación y unión de criollos, mestizos, indios, nativos y negros. En los primeros momentos se alineaban indistintamente en ambos bandos, patriota y realista, pero conforme pasaban los años y ganaba la causa patriota y ya no era posible reclutarlos compulsivamente para los hispanos, se abrió campo la posibilidad real de la independencia. Los criollos acomodados y con dominio del poder no hubieran podido hacerlo solos, sin las masas indígenas; pero igualmente estas no lo hubieran hecho por falta de recursos económicos y financieros que les hubiese facilitado para contar con un ejército armado, con disciplina y conocedor del arte de la guerra. Sus líderes en poco tiempo pudieron haber aprendido a organizar sus fuerzas y asumir su dirección, pero no supieron vencer internamente a los criollos españolizados que luchaban contra ellos aunque les ofrecían todos los logros que alcanzarían los sectores patriotas; pero no cumplieron e hicieron que los triunfos, movidos por intereses criollos y aun espańoles, fueran para ellos, que terminaron apode- 
rándose del nuevo Estado. En tanto que las masas indígenas y campesinas, siguen luchando por lo que la Independencia no les dio.

Se colige que el estudio sobre la Independencia es el mejor modo de acercarnos para recrearla y repensarla lo más objetivamente posible. Para ello debemos apartarnos de la versión oficial que desgraciadamente es la más difundida y engañosa. Pues alaba a los héroes militares, civiles y criollos, ha inventado una multitud de «precursores»; no se cansa en prodigar elogios a la inmensa travesía de los ejércitos a lo largo y ancho de las cordilleras. Mas la historia del lado de la población pobre y mayoritaria del país, de su gente, de sus héroes anónimos, de su aporte con sangre y su vida, aún no forma parte de la historia oficial. Obliga a seguir hurgando sobre las infinitas formas de protesta, resistencia, de luchas y movimientos que en aras de la libertad y de alcanzar los derechos civiles, económicos, sociales y políticos hicieron la gente del pueblo. Recordemos que «Sólo en medio siglo anterior a Túpac Amaru (17301780) hubo 112 rebeliones campesinas en el Perú...» (Macera 1985: 23).

\section{Dos proyectos independentistas}

a) Proyecto indígena campesino: se inició con Juan Santos Atahualpa, continuó más tarde con José Gabriel Condorcanqui, Túpac Amaru II, y con el protagonizado por los hermanos Angulo. Los tres fueron movimientos netamente indígenas y cholos. Participaron en todo el proceso de la guerra que se inició en el mismo momento de la conquista, porque las condiciones de explotación y dominación impuestas no cambiaron; la lucha por sus propios intereses, por su gente, por la defensa de sus tierras, por la expulsión del enemigo invasor, sigue vigente.

Los criollos que lideraron esta guerra los llamaron «hermanos naturales», "peruanos». Abolieron la palabra indio, los tributos y servicios personales. Les otorgaron libertad si hubiesen sembrado, cosechado y vendido; declararon el libre tráfico, podían disponer de sus tierras comunales, pero fueron muy pocos los indígenas que conocieron estas promesas y expectativas.

b) El criollo separatista y triunfador: fue el que ganó, fue de los criollos, de los colonos descendientes de los invasores, de los 'españoles americanos'. "La realidad así enfocada patentiza que nuestra Independencia po- lítica fue la obra 'revolucionaria' de los herederos de los conquistadores y no de los conquistados. Como una 'revolución' manipulada desde arriba, por los aristócratas y oligarcas terratenientes y comerciantes, el hecho explica por qué no hubo quién cuestionara el meollo del sistema colonial» (Espinoza 2016: 38).

Por los grupos sociales o fracciones de clase que lideraron, por los resultados y objetivos logrados con esta guerra independentista, podemos decir que fue eminentemente de carácter criollo, es la historia que oficialmente se difunde y conoce. Con el devenir de las acciones de lucha, este sector tuvo la oportunidad de ir creando la conciencia nacional con la difusión de publicaciones como El Mercurio Peruano y con la participación de lo más graneado de erudición peruana La Sociedad Amantes del País, representando a los criollos acomodados y a sus intereses (García 2007: 26).

\section{Los montoneros en el proceso de la Independencia}

La historiografía peruana rescata poca información acerca de la participación de la masa campesina aborigen en el proceso de la Independencia, pese a la abundante información existente en los archivos regionales y parroquiales, en la memoria colectiva y oralidad de la gente. Es urgente superar la tendencia a desconocer las acciones de armas de los grupos sociales del área andina y selvática así como su contribución al movimiento revolucionario y al rompimiento con la metrópoli colonialista. Su participación en la guerra lo hicieron organizándose en partidas, montoneras y guerrillas, formas que se adecuaban a una organización militar rural caracterizadas por la escasa disponibilidad de armamentos bélicos, con armas elaboradas con recursos de la zona como: lanzas, hondas, arcos, galgas y piedras; al número de integrantes, a la alimentación, a los pocos implementos logísticos disponibles. No olvidemos su conocimiento del terreno agreste de la sierra y difícil en la selva. Su origen y lugar de nacimiento, su estrecha relación familiar y su pertenencia a su comunidad, fue el real móvil de su lucha por la defensa de sus familiares y bienes.

Se afirma que "Los montoneros en esta gesta no tenían una propuesta política y económica, solo buscaban reivindicaciones étnicas culturales y de justicia social ante el abuso de los gamonales. Pues los campesinos, los esclavos negros y libertos tuvieron una 
presencia directa en la proclamación de la independencia, pero fueron demagógicamente persuadidos para luchar por los intereses de los criollos patriotas» (Coronado 2010: 10).

Durante esta guerra se relacionaron y se incorporaron a las fuerzas de los criollos patriotas, por tres razones: los ofrecimientos que les hacían de liberarlos de los tributos, las mitas, el yanaconaje, la esclavitud y otras formas de opresión social; la lenta identificación con lo que era suyo desde el incanato, es decir, una toma de conciencia nacional $y$, la tercera, la que en forma compulsiva se hacía con estos campesinos. Así las reivindicaciones por la educación, por la desaparición de la servidumbre y los latifundios, haciendas, obrajes, minas, la eliminación de la esclavitud y leva forzada hizo posible que esta masa de campesinos montoneros al incorporarse al ejército patriota, llegara a constituirse en la sección fundamental del ejército patriota no sólo por ser la mayoría, sino también por su conocimiento de las breñas andinas, por el manejo de galgas y armas de lucha cuerpo a cuerpo que demostraron su valentía.

Sobre las montoneras, diferentes historiadores acotan: «Los montoneros conformaron las fuerzas militares irregulares del ejército liberador, en la lucha contra los espańoles, daban informaciones exactas sobre el enemigo, actuaban como logística del Ejército Libertador. Proveían de alimentación, curaban a los heridos y participaban en la lucha sorpresiva de cuerpo a cuerpo contra el enemigo, bloqueando sus objetivos militares y sobre todo mermando la moral del ejército realista» (Quiroz 2014).

Por su parte, Virgilio Roel define a los montoneros como «Una agrupación de indios que atacaba en montón y que constituyeron el núcleo fundamental de los ejércitos (campesinos pobres, hombres y mujeres del campo, de las haciendas, de las minas y los arrieros) sumados a los negros cimarrones de la costa que estaban sometidos a la explotación y expoliación del Estado colonial. Se caracterizaban en cuanto a su conformación con un número mayoritario de indígenas, negros cimarrones, comandados por criollos y autoridades locales». "Los más duros combates y lucha de los montoneros se dieron en la sierra, en los valle del río Mantaro y en la sierra de Ayacucho (Cangallo), donde el enfrentamiento fue cuerpo a cuerpo, murieron miles de ellos, muchos de los pueblos también desaparecieron por los incendios y el saqueo cometidos por los espańoles en represalia por la acción de los montoneros que los tenían en jaque. Los terratenientes criollos de la zona andina, la geografía agreste y la presencia de los campesinos siervos que conocían las zonas, garantizaban el triunfo de los patriotas» (Roel 1997: 46).

Las montoneras dieron origen a las guerrillas de composición más organizada, con mayor capacidad de movimiento y de ataque sorpresivo. Mas este tipo de organización militar campesina no fue considerada como una acción patriótica por quienes dirigieron el proceso, sino simplemente como una forma de defensa y de complemento. «Su falta de preparación militar, que la impulsaba a atacar al enemigo en forma desconcertada y sin objetivo táctico preconcebido; el deseo de venganza que lo orienta hacia él con las consiguientes consecuencias del saqueo de los pueblos y la apropiación de víveres y pertrechos» (Rivera Serna 1958: 18).

También se puede afirmar que las montoneras eran formaciones militares irregulares constituidas generalmente por individuos de una misma localidad, que brindan su apoyo armado a una determinada causa o caudillo. El campesino, en su lucha contra el dominio colonial hispánico, se organizó en guerrillas y montoneras, así «Los montoneros - imprescindibles en la victoria patriota - no provenían, como es evidente de las capas más altas de la sociedad colonial» (Flores Galindo 1987: 216).

\section{Paticipación de los campesinos indígenas en esta guerra}

Como se comprenderá la incorporación de los campesinos a las partidas, montoneras y guerrillas no fue fácil, como se ha señalado fue todo un proceso, su resistencia y la falta de entusiasmo por la guerra se motivaba porque persistían las formas de exacción económica y de dependencia personal y, no obstante los ofrecimientos de no afectar su economía, ellos veían que continuaba la incautación del ganado familiar y comunal por la necesidad de alimentar a un creciente número de soldados. Estas condiciones favorecieron las deserciones de soldados indígenas y sea lo común cada día. Como no podían fusilar a todos los desertores, realistas y patriotas, preferían cortar una o las dos orejas a los prófugos. Pululaban los desorejados por completo; y a pesar de ello, los huidos seguían 
aumentando. Los realistas optaron por celebrar festividades, para atrapar con facilidad a los habitantes congregados y confiscar sus alimentos que portaban para esas fiestas. Los mestizos, los esclavos y libertos, los siervos y yanaconas, los runas en general, en el ejército no veían progreso en el trato humano, siguieron en las mismas condiciones de explotación.

Pese a todo ello, el movimiento guerrillero se fortaleció y fue notable en la sierra central. Especialmente con la primera expedición de Álvarez de Arenales, oficial que las formó, les dio armamento y pertrechos además de restituir el orden al nombrar autoridades políticas patriotas. Dejó 900 efectivos, dichos guerrilleros hicieron denuedos para contener a los generales españoles, esto sirvió para el surgimiento de líderes indígenas con aceptación entre los de su clase y raza. Además, las masas de guerrilleros sobresalían por su sobriedad — pues comían y libaban poco-, conformando buenos cuerpos de combate, aunque sin ninguna posición duradera. Bolívar imprimió otro dinamismo. Ordenó la leva de todo "hombre útil para las armas». Disposición que afectó en lo medular a las provincias del departamento de Trujillo (más tarde La Libertad), cuyos distritos se vieron - por esta razón - despoblados de varones jóvenes y adultos, y también de sus equinos, mulares, vacunos, ovejunos y productos agrícolas y textiles. Lo mismo hacía el virrey en el sur (Espinoza 2014).

Con la proclamación de la Independencia, los primeros decretos sanmartinianos fueron similares a los de la Corte de Cádiz. Pues se buscaba la incorporación del runa andino a las filas patrióticas, les llamaron «hermanos naturales» y los calificaron de «peruanos». Abolieron la palabra indio, los tributos y servicios personales. Les otorgaron libertad para cuanto hubiesen podido sembrar, cosechar y vender, incluso tabaco, para lo cual fue extinguido el estanco, aunque persistieron las alcabalas. Pocos indígenas pudieron conocer y experimentar las promesas y expectativas, porque como se ha hecho habitual en el Perú, la norma y los predicamentos quedan en la letra.

\section{Corrientes libertadoras: San Martín y Bolívar}

La intervención de las fuerzas libertadoras, permitieron consolidar la independencia de sus países ya liberados: Argentina, Chile y la Gran Colombia; eran conscientes de la necesidad impostergable de derribar al poder de españoles y criollos en el Perú, su presencia vigorosa de estos ponía en peligro la libertad del resto de América. La intervención se efectivizó con la llegada de escuadras y expediciones armadas. Primero José de San Martín (1820), y poco después Simón Bolívar (1823).

\section{Los guerrilleros de la sierra central}

Luchadores contra la opresión y la invasión foránea los campesinos indígenas del centro demostraron su valentía y heroicidad desde el inicio mismo de la Colonia, un breve repaso muestra estos hechos: Manco Inca en Wankamayo (Mantaro) con el primer grito separatista (1536). Destacan los héroes rebeldes Cristóbal Callavallauri en 1565 y Carlos Apoalaya (1666), ambos de Chupaca. Melchor Julián Mayta Canchari (1710) en Acolla, torturado tres días seguidos y arrastrado por un caballo cabalgado por un negro llamado Jacinto Hurtado tras haberse revelado contra los hacendados españoles de Yanamarca en defensa de sus tierras. Cristóbal Huayna Atoc del pueblo de Junín en 1735 defendió a los arrieros indígenas contra los propietarios de minas. La revuelta de Casimiro Lambato (1752) en Jauja. También Ignacio Torote, cacique asháninka, sublevado en 1737, el movimiento del Apu Inga Juan Santos Atahualpa, que liberó la Selva central. En este movimiento destaca la heroína Ana de Tarma, con un grupo de corajudas mujeres tarmeñas tuvieron intimidados al Intendente Benito Troncoso al igual que a un sanguinario realista Pedro de Milla Campo, derrotándolos en las batallas de Cerro la Sal, río Perené y Nijandaris. Nicolás Dávila Astocuri en 1781 en Jauja, con apoyo de su madre Josefa Astocuri Limaylla, liberó del pago de mitas y el pontazgo en Huancayo (Castro: 37).

\section{La expedición libertadora de Antonio Álvarez de Arenales}

Luego de dos meses en Pisco, José de San Martín busca un lugar más estratégico, decide trasladarse a Huaura y ordena a Álvarez que se interne en la sierra central para insurreccionar a los pobladores y tender un cerco sobre Lima. Álvarez, comandante y estratega de la expedición libertadora de la Sierra Central, partió de Pisco el 5 de octubre de 1820 y cubrió Ica, 


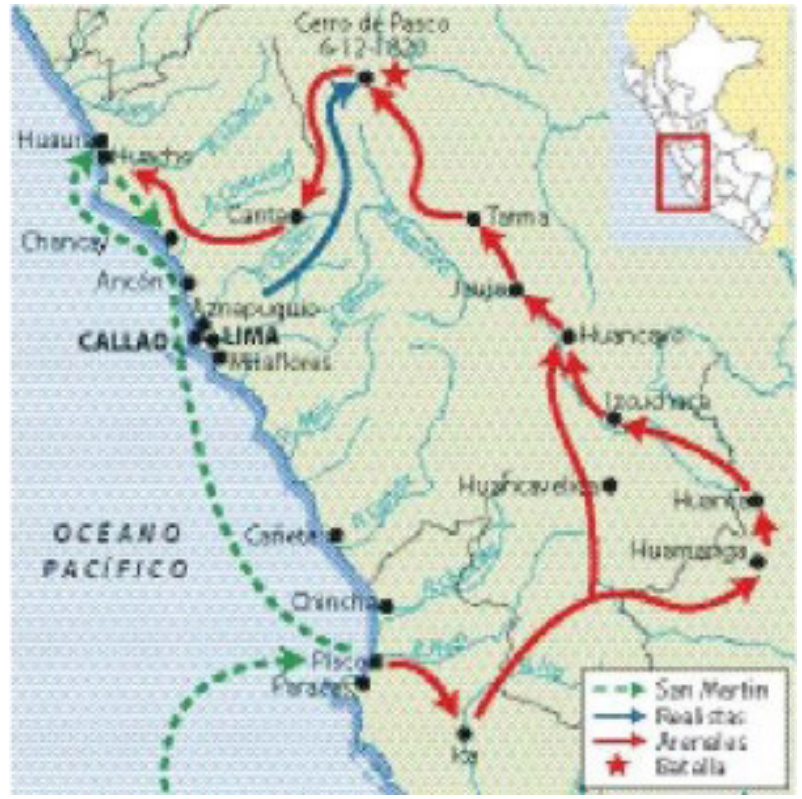

Expedición de Antonio de Arenales

Cangallo, Huamanga, Huanta, Huancayo, Jauja, Tarma hasta Cerro de Pasco con 1242 hombres, llegó a Huaura el 8 de enero de 1821 (Basadre, citado por Mayta y Canchari 2018: 40).

Pudo conocer la situación real de los realistas, soliviantar a las poblaciones contra los godos, hacer una gran propaganda y hacer que los pueblos proclamen su independencia y elijan sus propias autoridades y desconocer al virrey Pezuela. Se realizaron varias batallas, en Puchococha-Acolla, donde el mayor Lavalle derrotó a los realistas con montoneros acollinos. Inmolándose Rudecindo Mayta. Continuó a Tarma y Cerro de Pasco, aquí se enfrentaron victoriosamente con O'Reilly en Uliachín y Patarcocha el 6 de diciembre. El 29 de diciembre en Azapampa las tropas del cura guerrillero Félix Aldao, fueron vilmente masacradas por Ricafort, sucumbiendo más de quinientos héroes wuancas. Los campesinos luchaban y ofrendaban su vida, morían en aras de la patria, fue su aporte en vidas humanas.

La difícil orografía, amplia y accidentada del territorio, en la cual se realizaron las acciones militares entre 1821 y 1824 , abarcaba desde el nudo de Pasco y las cadenas oriental y occidental de la cordillera de los Andes, en ellas, según refiere Waldemar Espinoza: "Los guerrilleros se posicionaron en los pasos estratégicos que comunicaban las cabeceras de la costa con la sierra u ovillándose a lo largo de las punas de
Yauli, Junín y Pasco constituyeron la mejor garantía, para la preparación del ejército libertador del norte». No olvidemos que el minero y el arriero en Cerro de Pasco y Junín jugaron un papel importante. Antonio Álvarez de Arenales (octubre 1820), recorrió Cangallo, Huamanga, Huanta, Huancayo, Jauja, Tarma y Cerro de Pasco para unirse a San Martín en Huaura, significó el surgimiento de un vasto movimiento patriota, que con la derrota a O'Relly, levantó las llamas del movimiento libertario.

\section{Los pueblos del centro y la proclamación de su Independencia}

Son varios los investigadores que han estudiado la resistencia y la lucha de los pueblos del Centro por la independencia y particularmente la suya, los menciono en los párrafos siguientes.

Según Macera, «La expedición de Álvarez de Arenales tuvo además un éxito político... Diversas poblaciones juraron su independencia y eligieron sus autoridades. Los indígenas no solo se pronunciaron a favor de su independencia y eligieron a sus autoridades, sino que prometieron defenderla aun con sus vidas al conocer que San Martín había abolido el tributo» (Mayta y Canchari 2018: 45-46).

\subsection{La independencia de Huamanga. Refiere el} coronel tucumano, José Roca, abanderado de los granaderos a caballo: "Posesionados en la ciudad de Huamanga capital del departamento del mismo nombre, el general tomó informes del estado y posiciones del enemigo. Dispuso también que el pueblo jurase la independencia, ceremonia que se verificó con la mayor pompa y lucimiento, con misa de gracias» (Mayta y Canchari 2018: 44).

8.2. La independencia de Huancayo. El 20 de noviembre de 1820, en la plaza de Huamanmarca: «Huancayo será desde este instante, libre del dominio espańol o de cualquier otra nación extranjera, porque así los juramos sus hijos ante el dios de nuestros padres, en el altar de la patria libre! El RP Estanislao Márquez de las Casas redactó el Acta de la independencia de Huancayo y Jauja (Mayta y Canchari 2018: 49).

Este hecho provocó la furia de los españoles comandados por Mariano Ricafort que se trasladaron 
desde el Cusco hasta el valle del Mantaro, avanzó arrasando e incendiando a los pueblos, su intención era castigar a Huancayo para escarmiento de los demás pueblos. En Huancayo el sacerdote José Félix Aldao, en menos de un mes logró reunir a unos diez mil bravos Wuancas. El 28 de diciembre Ricafort alevosamente incendió Viqus y Huayucachi, pueblos cerca de Huancayo. Un día después Ricafort y su ejército realista aparecieron en Azapampa con 1300 hombres bien armados, mientras que los patriotas con una masa de 10000 indios armados de lanzas, rejones, hondas y escopetas casi inservibles. La batalla fue muy dura, las armas decidieron a favor de los realistas, el resultado, una masacre. «Las tropas de Ricafort rodearon y asaltaron Huancayo. Saquearon al vecindario y degollaron a más de 1000 indefensos pobladores. Los sanguinarios españoles persiguieron a los patriotas hasta quebrada honda»(Mayta y Canchari 2018: 96). Paz Soldán refiere que «El castigo que aplicó a los pueblos wancas fue cruel y monstruoso: masacres, incendios, fusilamientos, violaciones, degüellos», Mitre (1887) dice: «Pasó a cuchillo a más de quinientos hombres indefensos» (ídem).

\subsection{Proclamación y jura de la Independencia en} Jauja. 22 noviembre de 1820, con la presencia de Arenales proclamaron y juraron su independencia, con mucho entusiasmo. "Descendientes de los indómitos Hatun Xauxas, juráis ser un pueblo libre e independiente de los reyes de Espańa y de toda dominación extranjera, defender la religión católica y la libertad aún a costa de sus vidas» ¡Sí juramos ser libres!

Jauja: Inca e hispana, a pesar de su fundación española ha sido y seguirá siendo el paladín de la libertad. Luego de perseguir y atacar al ejército realista que pasó por Jauja en dirección a Tarma, el mayor argentino Manuel Lavalle persiguiendo al realista José Montenegro y Ubalde con la orden de Arenales de alcanzarlo y aniquilarlo. En San Lorenzo, Ataura y Maquinhuayo causaron grandes estragos a la retaguardia del ejército realista.

Prócer Alejo Martínez Lira, encargado de proclamar la independencia de Jauja, fue capitán del Regimiento de los Granaderos Cívicos. De él, Waldemar Espinoza dice: "He aquí un hombre que permanece verdaderamente ignorado. He aquí a un patriota que, desde un comienzo, dio las pruebas más inequívocas de su adhesión al régimen instaurado por
San Martín y Bolívar. Un jaujino que permaneció invariable a la causa de la Independencia y a los principios republicanos. Un jaujino que no tuvo otro deseo que la libertad del Perú y América. Un peruano que jamás traicionó el compromiso que contrajo desde un comienzo y cuya conducta, honor y decoro nunca desmerecieron la personalidad de un oficial honrado" (Mayta y Canchari 2018: 76).

\subsection{Proclama y jura de la independencia en Tarma.} El último gobernador e intendente de Tarma, general Joseph González, huyó hacia Lima ante la proximidad de la expedición libertadora. Por orden de Álvarez de Arenales, el coronel Manuel Rojas ataca a los realistas y logra tomar varios prisioneros, además de 6 piezas de artillería, 500 fusiles y 50000 cartuchos. El pueblo tarmeño encabezado por el argentino residente en Tarma Francisco de Paula Otero, ayuda a Rojas y la noche del 25 de noviembre reciben apoteósicamente al grueso del Ejército patriota comandado por Antonio Álvarez. Por designación del Cabildo, Francisco de Paula Otero el 28 de noviembre de 1820 proclamó la Independencia de Tarma, al día siguiente se abolieron las contribuciones de tributos, los estancos y se reconoció el libre tráfico del comercio. Su misión fue sostener a los beligerantes, continuar la propaganda política e impedir o retardar cualquier empresa de las tropas realistas sobre la retaguardia de la expedición libertadora (ídem).

\subsection{Proclama y jura de la Independencia en Cerro}

de Pasco. "Durante la Colonia y buena parte de la República, hubo numerosas denuncias, protestas y rebelión anticolonial-feudal, los conflictos sociales fueron numerosos. La lucha contra el gobierno colonial fue intensa en los siglos XVI, XVII y XVIII, tanto en las áreas rurales como en el espacio minero. Las ideas y noticias libertarias circularon por los caminos comerciales desde Lima a Cerro de Pasco por los valles del Chillón o del Rímac.

La batalla de Cerro de Pasco. La expedición de Álvarez de Arenales en su marcha libertaria llegó el 5 de diciembre a Yanamate, a $7 \mathrm{~km}$ de Cerro, allí planeó la estrategia para atacar al enemigo que acampaba en Cerro de Pasco. Desde Villa de Paco, el 6 de diciembre muy de madrugada el ejército patriota se dirigió al encuentro del enemigo, superó las lagunas de Yanamate y Chaquicocha, treparon la montaña 
inaccesible de Uliachín, y a las 8 ya la tenía copada, este cerro Patarcocha estaba como una alfombra de nieve que se derretía y se mezclaba con la sangre de los defensores de la patria, tomando posesión conforme a lo planificado. Los montoneros indígenas estaban en la cima en tanto que las 4 piezas de artillería estratégicamente colocadas operaron de inmediato, los enemigos ante el primer disparo de la artillería patriota salieron asustados y se posicionaron en la salida hacia Lima.

Cientos de montoneros cazadores pro realistas se ubicaron para defender el centro minero, pero también hubo cientos de indios de montoneros patriotas. Álvarez de Arenales, con el fuego de artillería que inició, obligó a los realistas a dar combate, los montoneros cazadores pro realistas se ubicaron para defender el centro minero, pero los cientos de indios de montoneros patriotas para combatirlos. La lucha fue sin cuartel, las columnas de ambos bandos se enfrentaban tenazmente y con mucho coraje, muchos de estos enemigos eran familiares pero estaban en bandos opuestos.

El apoyo del aguerrido pueblo cerreño que ansiaba su libertad fue decisivo para el triunfo. Con la fuerza, el pundonor y heroísmo que mostró el ejército patriota (menos de mil efectivos, contra 1400 de los godos) pudo dar fuertísimo golpe al enemigo que huyó en desbande cargando a cuestas su derrota. En esta lucha los realistas tuvieron 58 muertos, 15 heridos y 315 prisioneros, entre ellos estuvieron el coronel Diego O’Reilly y Andrés de Santa Cruz, más tarde presidente del Perú. Además cayeron en manos de los patriotas 2 piezas de artillería y 360 fusiles. Informados los indios que O'Reilly se retiraba con calma por el Chaupihuaranga, decidieron perseguirlo y lo apresaron en el pueblo de Baños, en la hacienda de Lauricocha, capturado fue llevado a Huaura y cuando meses después era enviado a España, prefirió suicidarse en alta mar.

El Cabildo y la Jura de la Independencia. Convocados por Álvarez de Arenales, el día 7 de diciembre en la plaza de Chaupimarca, se acantonaron a los vítores del pueblo cerreño el Estado Mayor del Ejército Libertador, los granaderos a caballo, los soldados y el pueblo, comandados por Antonio Álvarez y don Ramón Arias, Alcalde Mayor y Juez de la Patria. Reunidos en el Cabildo, se levantó don Ramón de Arias y dijo estas históricas palabras:
«¡Cerreños! ¿Juráis ante la cruz, el ser independientes de la Corona y Gobierno del Rey de España y ser fieles a la patria aún a costa de sus vidas? Mil voces a un solo tiempo, con emoción y al unísono dijeron: «iSí, juramos! y mil veces sí», sucediéndose un delirante entusiasmo, escuchándose vivas a la patria, al ejército libertador y descargas de fusilería hechas por las tropas del batallón Concordia de Pasco» (Pacheco 1989, citado por Mendoza 2012: 12). Inmediatamente se escuchó una salva de 21 cañonazos, hurras, repique de campanas, lágrimas y abrazos.

\subsection{Proclama y jura de la independencia en} Huánuco. La noble ciudad de los caballeros del Perú, fue escenario de la revolución popular de indios, mestizos, criollos y miembros del clero que acaudilló Juan José Crespo y Castillo. Las causas de esta revolución, según refiere Macera, fueron «Sociales y políticas. Los indígenas estaban descontentos no solo por los repartos de las mercaderías, sino también por el saqueo de sus cosechas y contra los abusos que cometían las autoridades españolas...» (citado por Mayta y Canchari 2018: 91). El clérigo Juan Durand fue uno de los más activos. En su celda almacenó armas y pólvora, en ella fueron preparadas las composiciones literarias y artísticas del movimiento.

Luego de las batallas de Uliachín y Patarcocha, consolidada la victoria patriota, los de Huánuco se aprestaron a derrotar por completo al ejército de Diego O'Reilly (capturado), deciden en cabildo adherirse a la causa libertaria, es así como el alcalde Eduardo Lúcar y Torre, el día 15 de diciembre de 1820, preside el acto en el cual el comisionado Nicolás Herrera con toda solemnidad dice: «Huanuqueños, juráis por Dios y una señal de la cruz el ser independientes de la corona y gobierno del Rey de Espańa y ser fieles a la patria», a lo que la multitud respondió emocionada: «iSí, juramos!».

\section{Declaración de la Independencia del Perú y su significado}

La independencia se proclamó en un ambiente rodeado por el temor social de los criollos ricos de Lima, pues la situación del ejército realista era insostenible debido a la presencia del ejército de San Martín en el norte, lo que hacían las guerrillas y montoneras en el cercado de Lima, el bloqueo del Callao por Cochrane, 
la acciones de Álvarez en el centro, la falta de alimentos y otros hizo que el virrey La Serna abandonara Lima dejando a su gente el control del Castillo del Real Felipe. "Los criollos ricos de Lima vivieron horas de angustia durante el lapso intermedio entre la salida de los españoles y el ingreso de San Martín. $\mathrm{Su}$ reacción fue de terror. Unos especulaban con la posibilidad de un alzamiento interno de los esclavos que vivían en la ciudad. Otros temían el saqueo de las montoneras compuestas principalmente por indios y mestizos. [...] Los criollos ricos de Lima temían que la guerra entre españoles y criollos terminara convirtiéndose en una guerra social de pobres contra ricos y de diversos grupos étnicos (indios, mestizos, negros) contra los blancos... Estos factores fueron decisivos para que el Cabildo de Lima votase en favor de la Independencia del Perú. No todos los que firmaron el acta de ese cabildo fueron patriotas. Muchos habían sido simpatizantes y colaboradores del régimen español y continuarían siéndolo. A todos los unía la defensa del orden y el sistema. Ahora lo representaba San Martín» [...] «Lo que a esos criollos y españoles ricos les importaba era que hubiese gobierno, que hubiese orden. [...] Quince días después de su ingreso a Lima, San Martín hizo declarar la Independencia del Perú el 28 de Julio de 1821, con un juramento que para él eran las tres fuentes principales de todo poder político: el pueblo, la justicia natural y Dios. El Perú es desde este momento libre e independiente por la voluntad general de los pueblos y por la justicia de su causa que Dios defiende» (Macera 1985: 81-82).

Sabemos cómo entró en crisis y ruina el imperio español, la guerra con Inglaterra, su alianza con Napoleón que luego la invadió, la abdicación del trono por Carlos IV a favor de su hijo Fernando VII, el nombramiento de José Bonaparte como emperador y otras condiciones que favorecen el surgimiento de ideas libertarias en los virreinatos. El pueblo español, ante tamaña crisis emprendió la lucha por la independencia de España. San Martín y Bolívar y otros revolucionarios retornaron a las colonias y entraron en acción en los virreinatos de Nueva Granada y Buenos Aires. En el Perú, en Lima, el 15 de julio de 1821 se firmó el Acta de Independencia. En ella se encuentran las firmas de los nobles y aristócratas criollos y espańoles, de alto clero y grandes comerciantes, pero no del pueblo. Firmaron esta acta: el Conde San Isidro, el Conde de la Vega del Ren, el Conde de Las lagunas, el
Marqués de Villafuerte, el Marqués de Monte Alegre, el Conde de Torreblanca, el Conde de Vista Florida, el Conde de San Juan de Lurigancho, el Marqués de Corpa, el Marqués de Casa Dávila y otros miembros de la aristocracia y terratenientes como: Xavier de Luna Pizarro, José de la Riva Agüero, Manuel Agustín de la Torre, Tomás e Ignacio Ortiz de Cevallos, Antonio Boza, Hipólito Unanue, José y Miguel de la Puente, Manuel A. Colmenares, Luis A. Naranjo, Mateo de Pro, Lorenzo Zárate, Francisco Moreyra y Matute, Manuel y José Ferreyros, Francisco Xavier Mariátegui, Antonio de Bedoya, José Pezet, Pedro Olaechea, Manuel Tudela, Agustín de Vivanco, Toribio de Alarco y otros cuyos apellidos que aún hoy los escuchamos, porque siempre tuvieron el poder y el gobierno del país. La población nativa y su representación, verdaderos dueños del territorio fueron omitidas totalmente, no obstante que su sangre y su vida fueron ofrendadas por la independencia.

Entendible al enteramos que "Cuando San Martín ingresó a Lima, no toleró la compañía de los batallones de indígenas, negros y cholos. De modo que estos no participaron ni vieron los ceremoniales de la proclamación de la Independencia el 28 de julio de 1821 , salvo los que vivían dentro de las murallas de la ciudad» (Espinoza 2014: 43).

Declarada la independencia según propuso San Martín, se nombró una comisión para la búsqueda de un rey para el Perú, debían traerlo de Europa y se estableció la nobleza para la corte del emperador con el nombre de la «Orden del Sol». De este grupo aristocrático salieron los primeros gobernantes de la nueva república. Entre ellos Hipólito Unanue, terrateniente de Cañete y fundador de la Orden del Sol, que había estado en el campo enemigo pasó a ser ministro de Hacienda llegando a ser presidente del Consejo de Gobierno (Ruiz 2018).

\section{Segunda expedición de Álvarez de Arenales a la sierra central}

Los españoles no reconocieron la Independencia peruana, Fernando VII en apogeo apoyaba a La Serna su virrey para que continúe con la guerra y pueda vencer a San Martín primero y Bolívar luego, y con ellos a sus huestes, especialmente a las partidas y guerrillas que los apoyaba. Era un momento especial, pues en cada pueblo la conciencia libertaria toma- 
ba cuerpo, traduciéndose en acciones; "Álvarez en Huaura informó a San Martín, que «desde el pueblo de Huamantanga en Canta (31/12/1820) se estaba 'electrizando' a los habitantes de la zona y que activaba la formación de compañías con el nombre de milicias» (Rivera Serna 1958:29).

Álvarez salió de Huaura, subió por Oyón para reunirse con los presidentes de los pueblos que habían declarado y juramentado la Independencia, Pasco, Tarma, Jauja, Huancayo pues ante la represalia realista se habían retirado de sus sedes. Con un ejército superior a 2500 hombres Valdez, Ricafort y Carratalá dominaban el vasto territorio desde San Mateo hasta Pasco y el valle del río Mantaro. Ante la presencia de Álvarez de Arenales, que de por sí les generaba temor, salieron presurosos de Cerro de Pasco con dirección a Lima, Valdez y Ricafort lo harían por Carhuacayán y Canta, en tanto que Carratalá iría por La Oroya, Yauli, San Mateo. Este último debido a las circunstancias adversas que se le presentaban prefirió la zona estratégica del Mantaro, llegó a Concepción ordenó el saqueo y cometió muchos atropellos a la población indefensa; lo mismo hizo con Chupaca, masacró a su gente y mandó a incendiar el pueblo, acciones criminales que las poblaciones no perdonaron, tuvo que huir hacia el sur, a Izcuchaca camino al encuentro con el virrey que se encontraba en el Cusco. Álvarez nuevamente toma posesión completa del Mantaro, restableciendo el dominio de los patriotas, retornaron las autoridades a sus cargos y el ejército patriota se preparaba para darles el golpe definitivo a los chapetones. «Se puso en contacto con los patriotas de Castrovirreyna, Pampas, Huanta, Huamanga y Cangallo, además formó compañías de 700 plazas con un plantel de oficiales, sargentos y cabos de lo mejor que tenía. Hecho esto regresó a Lima por La Oroya, San Mateo, esta expedición duró tres meses» (Rivera Serna 1958: 2).

La situación en los diversos pueblos y ciudades estaba muy convulsionada, la guerra no terminaba y había que asegurar el triunfo definitivo contra la lacra que significaban los realistas, cabe señalar las acciones de Risco y Otero quienes con sus montoneras y guerrillas atacaban y diezmaban a los invasores en Huarautambo, Huallanca, Huariaca, Yanahuanca a lo largo del valle de Chaupiguaranga, Cajatambo y Huaylas. Cuando Cerro de Pasco fue ocupado por unos 400 realistas, de inmediato fueron venci- dos por estos patriotas. En la gran planicie andina, en Huayllay, Quisque, Oyón y Cajatambo actuaba Dávalos poniendo en jaque y ocasionándoles bajas a los españoles. En realidad fueron muchas las acciones bélicas de los campesinos, ahora integrantes de las fuerzas patriotas, como la de Mariano Sánchez, comandante militar de Huánuco que reclutó 150 indígenas para enviarlos a engrosar las filas patriotas en Lima.

\section{Otras operaciones guerilleras entre 1821 y $1824^{1}$}

Muchos fueron los guerrilleros que intensificaron sus actividades contra el ejército realista acantonado en el valle del Mantaro, la meseta del Bombón y el nudo de Pasco, pues estos godos urgidos para llenar el rancho de sus huestes, saqueaban y se apropiaban el ganado, víveres y dinero con el propósito de retomar Lima, la capital. La modalidad de lucha de los guerrilleros era la de movimientos imprevistos, sorpresivos, adecuada a lo accidentado del terreno y que obstaculizaban la marcha y desplazamiento del enemigo, se organizaron las partidas que actuaban en los lugares señalados, impidiéndoles retornar a Lima. La lucha fue intensa y sin cuartel, brotaban como plantas fuertes y resistentes en todos los campos del escenario de la guerra, en la Pampa de Junín: (Reyes), Carhuamayo, Óndores, Pari, Ninacaca; en La Oroya, Yauli, Pachachaca y Chacapalca; en Huayllay, en Pacaraos, Parquín, Vichaycocha y Acos; en Canta, Huaros, Lachaqui y Huamantanga; en Huarochirí, San Damian, San Mateo y Matucana y también en Yauyos, Huancaya, Vitis y Tomas.

Rivera Serna sobre estos acontecimientos acota: «En Huánuco Guillermo Zevallos, Manuel Albagui, Ignacio Prado y José Espinoza enterados que el enemigo se acercaba, salieron al encuentro de Lóriga, que siguió a Huaypacha y luego a Ataura. Enterado

1 Guerrilla: Similar a la montonera, con mayor preparación militar y cívica, obedecían a un comando vinculado a San Martín, contaban con un capellán. Su preparación y competencia militar, así como sus aptitudes físicas y formación cívica eran indispensables por la responsabilidad que debían desempeñar en las acciones bélicas. Tenían una observancia de una severa disciplina militar y a las normas que debían sujetarse los jefes para la procura de víveres, forrajes dentro del aspecto estrictamente bélico, las circunstancias a operar contra el enemigo. La partida: era una fracción de la guerrilla, integrada por 50 a 100 efectivos de caballería o infantería, cuyo menor número le permitía operar con mayor facilidad. 
José María Guzmán sorprendió a la fuerza realista ocasionándole bajas y apoderándose de los pertrechos que dejó Lóriga. Custodio Álvarez y Buenaventura Gómez también organizaron Partidas en Cerro y Huánuco. Regularizaron el aspecto administrativo, hicieron un padrón de contribuyentes garantizando la recaudación. No obstante estas precauciones, el enemigo pudo ocupar nuevamente las pampas de Junín y la meseta del Bombón con 1500 efectivos, incendiando previamente el pueblo de Reyes y estableciendo sus avanzadas en Óndores, Carhuacayán y Uchumarca, cercanas a las estancias ganaderas de Corpacancha y Santa Ana donde requisaron el ganado, apoderándose 30000 cabezas de ganado ovino e incendiaron las viviendas de humildes moradores. Abandonaron la meseta de Junín y se trasladaron a Chacapalca distribuyendo sus avanzadas entre Yauli y la Oroya.

Álvarez, Otero e Isidoro Villar, volvieron a reorganizar las partidas y las guerrillas en Yanahuanca, Chaupiguaranga, en Yàntac, Aconcocha y apostaron partidas en San Mateo. El gobierno a pedido de estos jefes guerrilleros envío oficiales para que entrene a las partidas, estableciendo un buen servicio de espionaje para disponer de la información necesaria y oportuna. Estas partidas se fueron multiplicando, bajo la jefatura de Marcelino Carreño, José Fernández. Lo realistas en Julio 1822, irrumpieron en Tarma saquearon a la población y ejecutaron a los jefes patriotas Orrantia y Molero». "Los godos siempre en contra de las poblaciones indígenas no sólo lo saqueaban, sino también hurtaban las joyas, prendas valiosas de los templos como La Custodia, que al negarse a entregarla, los fusilaban. Ocurrió en el pueblo de Reyes» (Rivera Serna 1958: 34).

Continúa, «Fue a través de las Montoneras y las partidas que el pueblo participó en la brega por la independencia. La población indígena y mestiza, así como los negros y criollos formaron parte de estos grupos irregulares de gente armada, demostrando así que el poblador común y corriente del Perú estaba preparado para la guerra por la independencia, teniendo una idea más o menos general de la verdadera causa de la patria». (López Martínez 1974: 51), también está en las páginas de nuestra historia el hecho que refiere Rivera: "Cuando en Carampoma en julio de 1822 el capitán José Urbiola, señala que para admitir en las filas de ellas, debían convocarse a vecinos más aparentes, con poca familia y darles buen trato, para que la partida tome buen nombre»... «Sus beneficios se vieron prontamente, cuando el Comandante José Fernández sus efectivos de 170 hombres «que por su talla y destreza en el manejo de sus armas, podrían estar entre los más disciplinados batallones del ejército de la patria» (Rivera Serna, 1958: 20-21).

También los negros esclavos y libertos participaron en la independencia, pocos días después del desembarco en Pisco, se incorporaron 600 esclavos negros al ejército libertador. Entre ellos Ildefonso, encomendado a obtener informes y documentos de los realistas fue a Pisco, al amanecer es descubierto, se tira al mar y lo rescataron, cuando se le inquirió para que declarase dijo: «Moriría mil veces por la causa de la patria, más bien que obedecer otra vez a un español», fue acribillado por los realistas. Con los días en Pisco, San Martín informó que fueron 1100 efectivos negros que se enrolaron al ejército. Los esclavos cimarrones actuaron básicamente en la costa, luchando por reivindicaciones como por ejemplo su libertad, San Martín no se las dio.

\section{Guerrilleros indígenas en la culminación de la guerra}

\subsection{Del Congreso Constituyente y la presencia de Bolívar}

El Perú tuvo uno de sus momentos cumbres en la declaración de la independencia nacional el 28 de julio de 1821. San Martín convoca, el 27 de diciembre de 1821, al Primer Congreso Constituyente para que se instale en mayo pero por conflictos internos recién se instala el 20 de septiembre de 1822, al finalizar la juramentación, añadió: «Si cumpliereis lo que habéis jurado, Dios os premie; y, si no, Él y la Patria os lo demanden».

Este Congreso duró 3 años (1822-1825), fue muy elitista, casi todos limeños, aceptó la renuncia de San Martín, tuvo una marcada tendencia liberal, republicana y parlamentaria. Dieron las bases de la Primera Constitución Peruana que protegía «Los binomios libertad-igualdad y propiedad-seguridad, ambos destinados a tranquilizar tanto a los ricos que temían por su propiedad y su seguridad, como los 
pobres que deseaban libertad e igualdad» (Macera 1985: 94).

Desde los primeros días sus labores fueron intensas. La elaboración del Reglamento de la Junta Gubernativa; el otorgamiento del título de Generalísimo a don José de San Martín; la aprobación del Reglamento Interno; la definición de las Bases de la Constitución Política del Perú, promulgadas el 17 de diciembre de 1822. San Martín, dejó que el virrey abandonara tranquilamente Lima, producto de sus ideas monárquicas. Aprovecharon los godos para rearmarse en el rico valle del Mantaro, dirigiéndose luego al sur. La Serna instaló su sede principal en el Cusco, quedando el Perú dividido en dos: el Independiente, con Lima y el norte bajo el mandato de San Martín y el Virreinal con La Serna, el Cusco y Alto Perú. Luego de la conferencia de Guayaquil, San Martín optó por retirarse del suelo peruano.

Bolívar llegó al Perú en 1823 en medio de un caos político, de inmediato se le dio poderes absolutos, con el título de Dictador, los patriotas solo representaban la mitad de los soldados realistas. Tuvo que enfrentar a Riva Agüero y después a Torre Tagle que terminaron arrimándose a los españoles. Frente al desprestigio de los nobles, Bolívar consolidó su autoridad y prestigio. La situación en Lima era difícil, volvió a ser tomada por los Españoles en 1824, tenían además al Real Felipe. Decidió hacer frente a la situación, reorganizar el ejército con sede en Trujillo y la colaboración de Faustino Sánchez Carrión, de Huamachuco, quien de la nada sacó un nuevo ejército y a mediados de 1824 tenía más de 9,000 hombres. La iglesia y conventos entregaron sus joyas, el Estado vendió propiedades, los particulares contribuyeron con dinero y los pueblos dieron su apoyo financiero, los de Cajamarca y La Libertad en pocos meses produjeron telas, estribos, correajes, víveres etc. Así, inició su marcha desde Cajamarca en busca de realistas cuyas fuerzas llegaban a 16,000; con Canterac en Jauja unos 8 000, La Serna en Cusco con 1000; Valdez en Puno y Arequipa con unos 3,000 y en el alto Perú Olañeta 3,000.

2.1.1. Operaciones guerilleras. Un amplio número de guerrilleros intensificaron notablemente sus actividades contra el ejército realista acantonado en el valle del Mantaro, el Bombón y Pasco. La modali- dad de lucha, movimientos imprevistos, sorpresivos, para impedirlos retornar a Lima. En el ańo que llega Bolívar, 1823, existen disensiones entre Riva Agüero y una fracción del Congreso, todo ello generó una desorientación entre los jefes de la partidas que se manifiesta en la derrota del Batallón patriota Huánuco en las cercanías de Tarma.

Los realistas estaban posicionados en el centro del país: Monet en Pampas, con el batallón Arequipa y 400 hombres; Rodil y Lóriga con el Estado Mayor y 500 efectivos en Huancayo, más 200 jinetes de los Húsares y el Batallón de Infantería con 200 en Jauja; Rubín en Mito con 50 hombres, el segundo batallón imperial en Chupaca con 200, el comandante Lira en Chongos con 200 montoneros.

2.1.2. Partidas patriotas. Van a ser las mismas del año anterior, aunque algunas se pasaron al lado realista. Los escenarios fueron los puntos de acceso a la costa y no obstante las reiteradas incursiones realistas a Reyes (Junín) y Cerro, incrementaron grandemente su número y preparación militar, así en Ulcumayo con 100 efectivos bajo las órdenes de Antonio Elejalde. En Paucartambo a órdenes de José María Fresco, con 50 lanceros, también en Carhuamayo, Huachón, Ninacaca, Quiparacra. En Cachi Cachi, Apahuay, Huaschuli, Huay Huay al mando de Juan Vivas, Antonio Aliaga, Ciriaco Lovera, Hilarión Lozano.

\subsection{Los pueblos del centro del país por la emancipación}

Entre julio de 1821 y agosto de 1824 , al retirarse el virrey La Serna de Lima, la región central de Pasco, Junín, Huánuco, parte de Ancash y Huancavelica fue la que tuvo mayor movimiento y se dirimió superioridades entre las fuerzas contendientes; los pueblos de esta región se vieron comprometidos en la movilización de la maquinaria bélica patriótica, pues no solo brindaron hombres para la guerra sino que también con el volumen de su riqueza minera y agropecuaria para el sostenimiento del Ejército Unido Libertador (EUL). Muchos de estos pueblos sufrieron las funestas represalias del ejército realista. Fueron saqueados e incendiados Huayhuay, Llanama, Mullunya, Cingua, Comas, Andamarca, Acobamba, Chacapalca, este último luego de una proclama amenazante lanzada por Canterac. También se ejecutó a los jefes Miguel Ártica, 
Paula Huamán y Eufrasia Ramos, patriotas a quienes se les cortó la lengua previamente. Son muchos los pueblos que sufrieron la acción criminal de los chapetones. No olvidemos que fueron las guerrillas la vanguardia y el flanco del ejército regular patriota.

Ambos ejércitos estaban compuestos por hombres de diversas nacionalidades y grupos étnicos. En el patriota habían venezolanos, colombianos, quiteńos, peruanos, argentinos, chilenos acompañados de indios, mestizos y negros. Estos últimos también integraban el ejército realista sumando a los mismos españoles y a los criollos.

\subsection{Acciones de armas en Puruchuco y Huamantanga (Canta)}

Fueron muchas las acciones realizadas por la independencia, lamentablemente la mayoría de ellas no fueron registradas y han quedado en la memoria de la gente trasmitida de generación en generación. En setiembre de 1821, cuando el virrey La Serna huyó de Lima a Jauja, ordena Canterac acudir a Lima y el Callao para brindar protección a los españoles en el Real Felipe. La situación no le fue favorable por lo que el 17 de setiembre se vio obligado a retirarse a la sierra para encontrarse con La Serna. Lo hizo por la ruta del río Chillón cruzando las haciendas de Caballero, Chocas, Zapán y Macas, luego tomaría altura por el camino antiguo a Cerro de Pasco pasando por Puruchuco y Huamantanga. Por su parte, San Martín ordenó al general Las Heras atacar a Canterac, pues contaba con 700 infantes, 125 caballos y 500 montoneros, inició la persecución encomendando la vanguardia al coronel Miller quien avanzó hasta Macas sorprendiendo a los realistas en pleno rancho; éstos desconcertados iniciaron el desbande, a lo que Canterac ordenó fusilar a oficiales y soldados para intimidar a otros que lo hicieran. Precipitadamente el jefe realista se retiró hacia Puruchuco, el camino era agreste, pura subida, una cuesta interminable; Miller llegó a Socos, luego del descanso siguió la persecución. El día 22, ambos ejércitos subían por la cuesta, los realistas como se adelantaron hicieron trincheras pasando el Caracol a la altura de Tres Cruces. Miller es sorprendido por el brigadier Monet, que cubría la retirada de Canterac hacia Huamantanga, tendiéndole una emboscada sin éxito, pues Miller enrolló a la columna de Monet que quedó disuelta, muchos de sus soldados fueron prisioneros de los patriotas.

Los pobladores de Puruchuco huyeron ante la proximidad de Canterac que ordenó el saqueo y el incendio del pueblo. De inmediato se dirigieron a Huamantanga, pueblo que encontraron sin pobladores por lo que decidieron destruirlo y luego incendiarlo. Miller llegó a Puruchuco y de allí pasó a Huamantanga, cerca al pueblo se inició el combate el 23 de setiembre de 1821, a las 11 de mańana la lucha era encarnizada, la fuerza realista ubicada en el lugar estratégico, era muy superior a la peruana, efectivamente le dio el triunfo. Los patriotas demostraron que la lucha por la libertad y la independencia era lo más valioso que se podía tener y bien valía todo esfuerzo, sacrificio y hasta la vida. Enloquecidos los godos por su triunfo, comenzaron a saquear todas las casas hasta de los más humildes, prendieron fuego a todas ellas, salvándose solo el templo por disposición de Canterac, devoto del Cristo de Huamantanga. Canterac continuó su retirada al Centro. Ricardo Palma, en sus Tradiciones peruanas dice: "Es tradicional que al recibir en Lima, a fines de setiembre de 1821, la noticia de la destrucción de los dos pueblos (Puruchuco y Huamantanga), por los soldados del Rey, se cantaba en los barrios de Cocharcas y Malambo la siguiente copla:

¡Ni más Puruchuco, ni más Huamantanga!

¡Ni más papa lucha, ni más papa changa!

(Zavala Flores, E. F. en Casana 1938: 97-105)

\subsection{Las guerrillas y las batallas de Junín y Ayacucho}

Bolívar estableció su cuartel general en Trujillo. Su ejército se preparó para hacer frente al enemigo en tiempo relativamente breve. Entre tanto las partidas de guerrilleros intensificaban su obra de vigilancia y en los pasos estratégicos, espionaje en Ancash, Huánuco, en Oyón, Canta, San Mateo y Huarochirí. Se protegió la zona por donde iba a recorrer el ejército libertador. Sucre ordenó que se abastezca de municiones a las guerrillas y las que estaban en Reyes al mando de Fresco, pudieran con su jefe el comandante Peñaloza, cuidar del ganado para que no caiga en manos del enemigo. 
Miller luego de cumplir con lo encomendado de presionar a Canterac, se reintegró al grueso del Ejército Unido Libertador, y al mando de sus fuerzas, en la tarde del 5 de agosto en la hacienda Conocancha reanudó el comando de la caballería peruana. Su ejército llegó a Junín y encontró a Canterac. Cada uno de los ejércitos comenzó a bordear el lago Chinchaycocha, el día 6 emprendía la marcha en busca del enemigo, ya entre Carhuamayo camino a San Pedro de Cajas, un poco al sur de Reyes. Avisadas ambas fuerzas y dispuestas a la lucha, se dio la batalla de Junín, en la tarde de aquel día, los jinetes del norte peruano de Lambayeque y Pacasmayo, al mando de los oficiales Suárez y Rázuri, cayeron sobre unos de los flancos de la caballería realista que al final tuvo que retirarse derrotada, luego de un revés inicial, salieron victoriosas la fuerzas patriotas, cuya caballería fue la única que se comprometió en el encuentro. Canterac retrocedió y fue a encontrarse con el virrey en el Cusco para reorganizar sus tropas. También los patriotas siguieron al sur, se veían y retaban constantemente, iban en líneas paralelas. Sucre evitó enfrentarlas hasta ver el momento conveniente. Bolívar regresó a Lima por razones de comando: para ver la llegada de nuevas fuerzas colombianas, la presencia de buques espańoles y la existencia de 3000000 pesos de financiamiento (Macera 1985: 101-105).

Sucre continuó, pero en la Pampa de Ayacucho, cerca de la Quinua, el 9 de diciembre de 1824, 5700 soldados patriotas se enfrentaron a 9000 realistas. Antes de la batalla fue autorizado un encuentro entre hermanos y parientes que existían en ambos bandos. Con el triunfo en esta gran gesta se selló la independencia peruana y latinoamericana.

Luego del triunfo patriota, apresaron al virrey, habían muerto 1500 soldados realistas contra 300 patriotas. El virrey firmó la Capitulación de Ayacucho, hecho que no fue aceptado por Rodil que se había apoderado del Real Felipe y lo mantuvo hasta 1826 fecha en la que entregó, de las 2000 personas que tenía en un comienzo solo quedaron vivas 400 .

\subsection{Heroínas y héroes campesinos en el corazón del pueblo}

2.5.1. Las mujeres del pueblo. Campesinas y mineras participaron activamente en el ejército libertador para que pueda triunfar, participaron por el amor a su pueblo, a su gente, para liberarse de la explotación y abuso de los chapetones; no faltaron motivaciones demagógicas de los criollos y la coerción violenta para integrarlas al ejército. Estuvieron presentes en todas las etapas de la guerra, a veces lucharon como jefes militares, a veces en actividades administrativas, muchas alcanzaron jerarquía de heroínas y mártires. La mujer campesina cumplió un papel importante en el proceso de Independencia, con la parte logística, también luchaba cuerpo a cuerpo contra los enemigos, demostrando inteligencia, fuerza física y habilidad para vencer a sus rivales como en el combate en Concepción (Jauja, marzo 1821), donde pusieron una tenaz resistencia contra los españoles y muchas de ellas se inmolaron en el campo de batalla, fueron salvajemente torturadas para que delataran a sus familiares o compañeros de lucha, pero ellas prefirieron el silencio por sus vidas. Es el caso de Paulina Huamán, Eufrasia Ramos y María Parado de Bellido cuyos cuerpos fueron cercenados por el sable del opresor español. Estas panacunas (mujeres campesinas corajudas), vieron caer sus cuerpos por los sables y disparos españoles, pero nunca claudicaron por su principio de libertad y lealtad (Coronado 2006: 15).

Puede afirmarse que fueron varios miles los integrantes de las guerrillas y entre ellos estuvieron las mujeres que como los hombres, provenían de diversos pueblos andinos: Ayacucho, Canta, Huarochirí, Santa Eulalia, Tarma, Jauja, Concepción, Huancayo, Cerro de Pasco, Chicla, Matucana, Huayucachi, Huamanmarca, Huancané, Achipampa, Chupaca, Acoria, Colcabamba, Acostambo, Pillichaca, Huaribamba, Chongos y Yauyos.

Los indígenas del lado patriota, acompañados de sus esposas, en muchas ocasiones derrotaron a los chapetones o frustraban sus acciones bélicas. En verdad los montoneros siempre estuvieron vinculados a las luchas sociales en contra del sistema y las clases sociales opresoras. Mantuvieron la idea del regreso del Inca, que se manifiesta a través del mito de Inkarri, es decir el retorno del gobierno Inca. Para expulsar a los españoles los criollos decidieron hacer un trabajo de persuasión colectiva con las masas indígenas, comenzaron por la sierra en donde desparramaron una serie de pasquines antirrealistas, colocados en los lugares críticos de las ciudades como Huamanga, Huanta, Cangallo, también realizaron sabotajes, amedren- 
tamiento y destrozos en uno y otro bando. Así, sus escritos decían:

Guantinos despertad, no tengáis.

Cuidado, sacudís vuestra tiranía

Procurad la libertad, acabad con los ladrones

Franceses, chapetones; mueran todos, todos.

Cangallo, Andahuaylas, Lucanas, unidos todos,

Afuera advenedizos, no consistáis subdelegados

Que son ladrones, no tengáis miedo.

Heroínas que jamás las olvidaremos fueron muchísimas en diferentes lugares y momentos de la guerra por la independencia. Entre ellas: Tomasa Tito Condemayta, estuvo entre los ocho condenados con Túpac Amaru, fue de las primeras avanzando desde Condemayo. Cecilia Túpac Amaru, murió asesinada en la cárcel del Cusco, Trinidad Celis de Neira, Bartolina Sisa, compañera de Túpac Catari, igual Gregoria Apaza que actuaba como juez para sentenciar a los espańoles y criollos realistas. Paulina Huamán y Eufrasia Ramos, Buenaventura Munive. También Francisca Aguirre, Rosa Arce, Manuela Beltrán, Santusa Canque, Paula Noguera, Ventura Monjarrás y muchísimas más en lugares y momentos diversos de esta guerra.

Micaela Bastidas Puyucahua (Tamburco, Cusco, 1744-1781) jugó un importante papel en nuestra historia, esposa y consejera de Túpac Amaru II es una precursora de la independencia hispanoamericana. En 1780 lideró, junto a su esposo, la gran rebelión anticolonial para acabar con el mal gobierno, las injustas reformas fiscales y los abusos contra los indios. Al fracasar la sublevación fue capturada y condenada al estrangulamiento. Murió junto a su esposo e hijo mayor el 18 de mayo de 1781 en la Plaza de Armas del Cusco.

Sus raíces fueron tanto africanas como amerindias, era conocida como zamba, producto del mestizaje entre africanos e indígenas. Poco antes de cumplir 16 años, se casó con el joven mestizo descendiente de la nobleza incaica José Gabriel. Realizó reclamos y solicitudes oficiales a las autoridades coloniales de Tinta, Cusco y Lima, para que los indígenas fueran liberados del trabajo obligatorio en las minas y exonerados del cumplimiento de la mita, obteniendo siempre negativas. Micaela, recibió en la infancia la

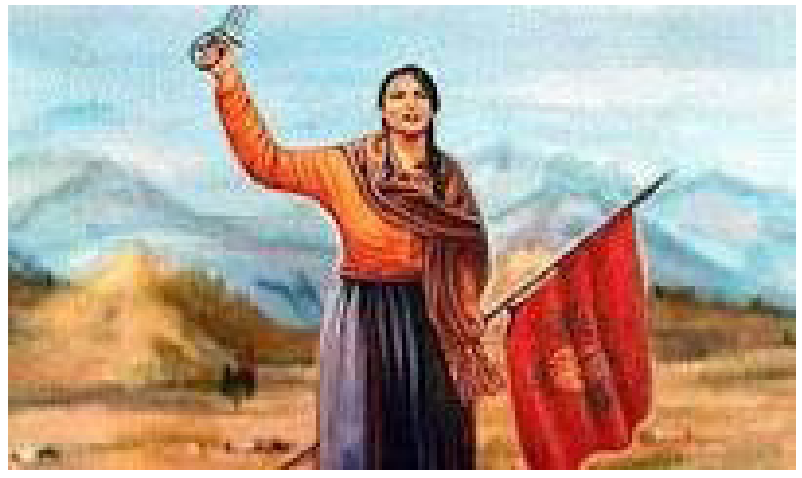

Micaela Bastidas

educación elemental en letras y artes que era usual en esa época para las mujeres. Su marido fue su maestro ideológico, ella rápidamente tomó conocimiento de la difícil situación de su gente y se involucró con la causa. Apoyaba firmemente, defendiendo y divulgando los postulados que harían resurgir la conciencia del derecho de los labriegos a liberar su tierra y su existencia de la mano opresora española. ${ }^{2}$

Buenaventura o Ventura Ccalamaqui, legendaria heroína indígena. Esta noble y valiente mujer huamanguina luchó contra la injusticia, la desigualdad social y abogó por los derechos y la libertad cuando las mujeres no tenían ningún derecho durante el virreinato. Es importante rescatar el liderazgo innato de esta heroína y muchas otras mujeres que aún permanecen en el olvido. Ventura Ccalamaqui se levantó en Huamanga, Ayacucho, el 31 de agosto de 1814 junto con cientos de mujeres campesinas para apoyar y dar paso triunfal al ejército insurgente del Cusco. Dio su apoyo a la revolución encabezada por el brigadier Pumacahua. Reunió a cientos de mujeres campesinas en la ciudad de Huamanga, para enfrentar a las tropas españolas invasoras. Mujer valiente y de sangre campesina, seguida de un enorme grupo de mujeres se dirigió al entonces cuartel de Santa Catalina y realizó un memorable motín desafiando al destacamento de la monarquía española en esta ciudad. Mujer desafiante, aguerrida, con las manos en alto frente al cañón enemigo. Ventura Ccalamaqui, ha sido una mujer de belleza natural, con un don disuasivo, casi siempre con las mangas de su blusa remangada y con un carácter resuelto a luchar contra la

2 https://es.wikipedia.org/wiki/Virrey_del_Perú, editada el 8 nov iembre de 2018 a las 19: 44). 
injusticia. «El historiador Abdón Yaranga la identifica como una montonera o morochuca, que descolló en el levantamiento de 1814 en Huamanga», «El ejemplo de Ventura Ccalamaqui y muchas otras mujeres valientes olvidadas, traspasa las fronteras y su presencia en la historia continental es un ejemplo para las generaciones del nuevo milenio» (Bustamante 2018).

Emeteria Ríos de Palomo, heroína canteña. Nació en San Agustín de Pariac, antiguo pueblo de Huayopampa del distrito de Atavillos Bajo, provincia de Canta, hoy Huaral; fue una aguerrida y valerosa patriota, identificada con los ideales de la causa emancipadora del Perú, tuvo una participación directa en la resistencia, con las guerrillas se organizaron en Atavillos Bajo para erradicar definitivamente de nuestro suelo a los españoles. En setiembre de 1823, el sanguinario Canterac, jefe del ejército español, después de vencer a los patriotas en Huamantanga, Quipán, Marco y Puruchuco, llegó al pueblo de San Agustín de Pariac. Según relata el huayopampino Roberto Aquino, la humilde compatriota encomendada al cuidado del ganado del patrón San Agustín, se negó a dar información sobre el paradero de los patriotas y del ganado que necesitaba el ejército realista para el rancho. La actitud valiente de Emeteria Ríos de Palomo, indignó a José de Canterac, quien ante tal negativa, ordenó su fusilamiento.

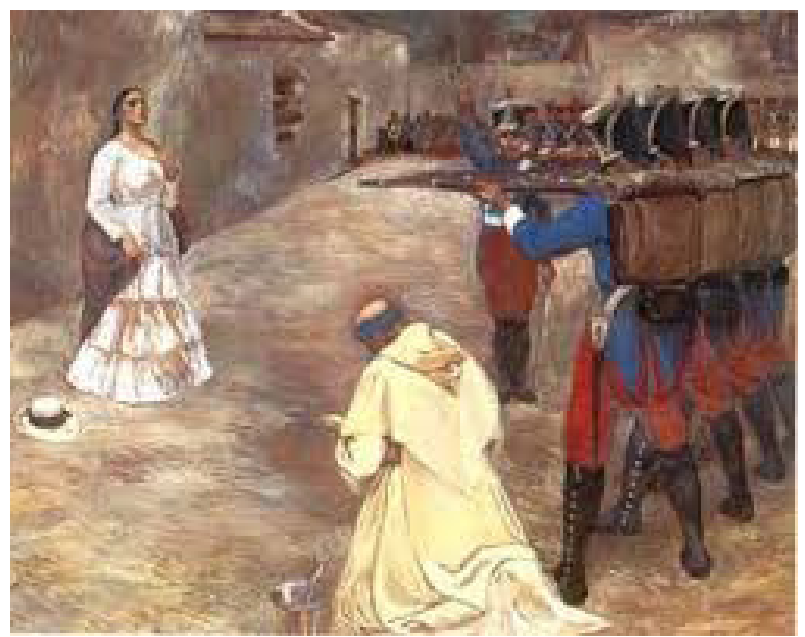

Ejecución de Emeteria Ríos de Palomo

Emeteria con su sangre, contribuyó para que la patria se concibiera libre. En el año 2010 la Municipalidad Provincial de Huaral le otorga el reconocimiento póstumo por su "Acción valerosa", distinguiéndola como «Hija Emérita de la Provincia de Huaral» por su sacrificio, valentía, coraje y contribución en la lucha por la Independencia del Perú.

Su labor de información y comunicación con las fuerzas patriotas era muy importante para conocer los movimientos del enemigo, pero fue capturada por Canterac y hecha prisionera. Torturada atrozmente para delatar a los guerrilleros y conspiradores, con mucha valentía soportó el suplicio y de sus labios los españoles no pudieron arrancar nada. Resistió todo con estoicismo y no traicionó a su gente ni a la causa. Impotentes ante tal muestra de heroicidad, no les quedó otro camino que decretar su muerte y fue condenada al fusilamiento en la Plaza de la Villa de San Agustín.

La mañana del 29 de setiembre de 1821, sus ojos vieron por última vez la luz del día. Ante el pelotón de fusilamiento levantó con altivez el rostro y gritó a todo pulmón ¡Viva el Perúi y su espíritu voló a la gloria y la inmortalidad. El general don José de San Martín le confirió el título de «Lancera de la Libertad», para muestra y orgullo de todos los canteños y huaralinos, es un deber cívico perennizar y resaltar su memoria como heroína.

María Parado de Bellido, con larga trayectoria en su lucha por la libertad, cuando sucedió el momento decisivo tenía alrededor de 60 años, de clase media, de estatura mediana, bien parecida y madre de siete hijos; su hijo mayor y su esposo luchaban al lado del montonero Cayetano Quirós, que atacaba y causó muchas bajas a Carratalá. Cuando éste llegó a Huamanga, estuvo interesadísimo en capturar a los agentes que los montoneros tenían en esa ciudad, los Morochucos atacaban y se retiraban, en una de esas traban combate con los de Carratalá, quien buscaba sorprender a Quirós. Los chapetones descubren en una chaqueta una comunicación que contiene avisos anticipados minuciosos y exactos de la expedición española a Socos Vinchos trasmitida de Huamanga a la montonera de Quirós. Se descubre que el destinatario es Mariano Bellido, esposo de María Parado de Bellido, y ella la remitente.

El 24 de marzo de 1822 los esbirros de Carratalá invaden su casa, la detienen y conducen a la cárcel, confiscan sus bienes y la amenazan de muerte. En la cárcel la torturan con interrogatorios toda la noche y ella solo dijo no sé nada. El 26 la someten a Consejo 
de Guerra y sentencian pasarla por las armas, se le comunica y ella mantiene su carácter tranquilo, con una heroica serenidad con que saldrá al suplicio. No obstante que la sociedad huamanguina en pleno pide el indulto, señalando que no es insurgente, pero nadie escuchó. Llevada de la prisión a la plaza principal, es acusada de delito de lesa majestad por haber traicionado al Rey y por tanto morirá. Ante los interrogatorios se niega a declarar. Le dicen: «Por última vez, di, ¿quién es tu cómplice?», responde: «Nadie. No he venido aquí a delatar sino a morir...». Mira al cielo azul y momentos después suenan cuatro disparos, dos balas le atraviesan el cráneo (Coronado 2006: 53).

Heroínas Toledo, en Concepción tres damas, María Ramos de Toledo (madre) y su dos hijas: Cleofé e Higinia Toledo Ramos, hijas de Pedro Toledo, argentino. En esos días el patriota Aldao, que operaba en Cerro de Pasco, había dejado un destacamento de caballería de 100 hombres en Concepción, que sirvieran en los puestos de observación y sean núcleos de concentración de los indígenas del valle. El 2 de marzo de 1821, a media noche, el realista Ricafort marcha a Concepción con toda clase de precauciones para caer de sorpresa y así no gastar municiones ni tener bajas. El 3 de marzo a las tres de la madrugada los realistas entraron sigilosamente a Concepción y atacaron por diversos puntos el cuartel patriota, los primeros disparos despertó al pueblo y se movilizó la guerrilla en defensa de la pequeña y única fuerza dejada en el valle; la confusión y el desorden manifiestos por la oscuridad produjo sorpresa y numerosas bajas entre los patriotas del pueblo que se defendió con escopetas y rejones.

Favorecidos por la oscuridad, la sorpresa y el conocimiento del área, escaparon y salvaron la vida de muchos. La soldadesca realista antes de retirarse cometió tropelías, el más vil pillaje e incendiaron la localidad. El pueblo de Concepción sufrió el primer holocausto en su lucha por la independencia. El realista Ricafort se retiró a Huancayo e Izcuchaca en donde lo esperaba Carratalá (narración de Germán Leguía y Martínez, citado por León Gonzáles Jesús 2018: 6).

Según Vargas Ugarte, el depuesto virrey Pezuela ordena a Ricafort retornar a Lima. Desde Izcuchaca y conocedor de la orden decide regresar por el Mantaro; pero se ve amenazado por Aldao desde Cerro de
Pasco, y desde Huamanga y Huancavelica por los montoneros de Huanta y Cangallo, por lo que pide ayuda a Canterac, quien ordena al coronel Jerónimo Valdés acantonado en Asnapuquio con 1200 hombres se traslade al centro y brinde ayuda a Ricafort.

Con sus batallones de infantería y caballería se internó por la quebrada del Rímac, pasando por Matucana, San Mateo para arrasar con las guerrillas llegadas de Huarochirí y Yauyos, luego de vencer los obstáculos naturales y la resistencia agresiva de los montoneros, fue a unirse con Ricafort. Penosamente pudo cruzar la cordillera y llegar a La Oroya y posteriormente al ubérrimo valle del Mantaro. Por su parte, Ricafort que había salido de Izcuchaca, el 9 de abril de1821, ya se encontraba en Huancayo, en tanto que Valdés llegó a Huaripampa en la noche del 8 de abril, para encontrarse y juntos golpear fuertemente a las montoneras y guerrillas del valle.

En Concepción no olvidaron la hecatombe que sufrieron el 3 de marzo, fue tan dolorosa que dejó huellas profundas en el corazón de este pueblo. Informados de la presencia de los espańoles, los pobladores destruyeron todos los puentes sobre el río Mantaro para impedir la reunión de las dos fuerzas de los chapetones. Excepto el «Puente Balsas» a la altura de Concepción; era amplio, hecho de mimbre y con pisos de madera. De ello se enteró Valdés y aceleró la marcha, se adelantó con un escuadrón de caballería y pudo alcanzar al pueblo de Mito, situado frente a Concepción (Vargas Ugarte, citado por León Gonzales 2018: 7-9).

Las mujeres de Concepción al mando de María Ramos de Toledo y sus dos hijas, organizaron a la población y prepararon la defensa del puente. Recibieron el apoyo de un sargento del batallón N. ${ }^{\circ} 11$, la mayoría de los varones se alistaron en las filas de Aldao, y solo quedaban unos cuantos ancianos. Tomaron la iniciativa para la defensa de la población, iniciativa que el general Álvarez de Arenales reconoce en su segunda campaña cuando llega a Concepción persiguiendo a Carratalá, y recibe la adhesión de los pobladores de Concepción. Rinde patriótico homenaje a las Toledo diciendo "debo consignar aquí un heroico acontecimiento que hace ilustre el nombre de este pueblo en la historia de la independencia americana [...] cuando la cabeza de la división Valdés comenzaba a desfilar por el puente ( 9 de abril) fue repentinamente aturdida por una descarga de la orilla opuesta, unos cuantos 
realistas fueron al agua y los demás volvieron atrás. Indignado Valdés con esta imprevista ocurrencia, mandó romper vivo fuego de mosquetería ayudado por las piezas de artillería ventajosamente situadas y cuyas balas desde corta distancia disparadas hicieron graves destrozos. En medio de esto Valdés mandó de nuevo que entrara una partida de húsares por el puente; pero las comandantes corrieron inmediatamente a la cabeza del puente con algunos de los suyos y se empeñaron en cortarlos. Esta operación ejecutada con presteza y entre el fuego de la metralla enemiga concluyó tan oportunamente que los que intentaron pasar fueron víctimas de su imprudencia y cayeron al agua. No por ello cesó el fuego; y en medio de él Valdés gritaba a los patriotas que se rindieran y que les perdonaría; pero las heroínas le contestaban del modo más heroico y firme. Así sostuvieron la acción paseando filas con marcial altivez y sin cesar de proclamar a su gente estimulándola a la pelea con la más ardorosa elocuencia» (León Gonzales 2018: 10).

Leguía y Martínez dice: «Las guerrilleras Toledo furtivamente con una osadía sin parangón, agazapándose, escurriéndose por el borde de los meandros y las aristas y muros, llegaron hasta la cabecera oriental y con celeridad y destreza increíble debilitaron sus tirantes de sustentación, pero de modo tal que solamente pudieron soportar su peso ligeramente al de su propia estructura» (León Gonzales 2018: 10-11).

"Cuando llegan los espańoles a la parte central del andamiaje del puente, se produce un estrepitoso crac y junto con el material que la constituía, caen los hombres al río, al torrente. Valdés se empecina en rehabilitar el puente y cuando sus hombres lo intentaron recibieron netamente repetidas descargas de fusilería. Enfrascándose en un tiroteo entre ambas partes, las patriotas comandadas por las Toledo, causando muchas bajas en el lado patriota y también de los espańoles. Las tres Toledo sostuvieron la acción paseando sus filas con marcial altivez sin cesar de proclamar a su gente, estimulándola con la más ardorosa elocuencia». El coronel Pedro José Gonzales en su informe señala que fueron 80 los patriotas defensores, precisa: "Cuando intentó pasar por ese sector — se refiere a Valdés- surgió la oposición de los guerrilleros que estaban en esta orilla del río y que impidieron el paso de los españoles, después de un fuerte tiroteo, las mataron tres hombres». La situación difícil y recordando lo sucedido el 3 de marzo, las Toledo decidieron el éxodo hacia las montañas de Comas, por Ocopa se internaron hacia los bosques, dejando sus hogares y llevándose cuanto pudieron, hasta el retorno de las fuerzas patriotas. "Una vez arreglados los puentes, las fuerzas de Ricafort y Valdés se juntan el 10 de abril y entraron a Concepción y el pueblo fue entregado al más completo pillaje de sus tropas». A ellas, San Martín las condecoró con la Medalla de vencedoras y la Banda Patriótica (León Gonzales 2018: 11-13).

\subsubsection{Mestizos indígenas, insignes patriotas en esta} guerra. Si bien es cierto que el ejército patriota estuvo al mando de criollos peruanos y extranjeros, los mestizos, los runas o indígenas y los negros conformaron la base de las fuerzas patriotas. Fueron los que integraban los ejércitos y luchaban, los campesinos y mineros, los yanaconas, los mitayos, los artesanos de los obrajes, fueron utilizados por ambos bandos, los hicieron pelear como carne de cañón aprovechándose de la sumisión, falta de organización y de una ideología indigenista nacional. Realmente estuvieron presentes en todas las etapas de la guerra, a veces lucharon como jefes militares, a veces en actividades administrativas, muchos alcanzaron jerarquía de héroes y mártires. Entre los muchos que brindaron su vida y a riesgo de no mencionar a cientos de ellos, señalaré a: Basilio Auqui 1814-1820, Ignacio Quispe Ninavilca (1820), Miguel Artica, Alejo y Baltazar Auqui 1822, Pedro Guaitalla 1822, Pedro Yauta 1822, Conde 1822, Félix Mendoza 1822, Cayetano Quirós 1822, entre otros.

Basilio Auqui. Nació en Incaraqay, Pampa Cangallo, desde joven tomó la causa patriota, se enroló a los Morochucos con los que utilizando la grandeza y rudeza de la Pampa, hostilizaban a los godos, los atacaban intempestivamente haciéndoles la vida insoportable y difícil. Participó en varias

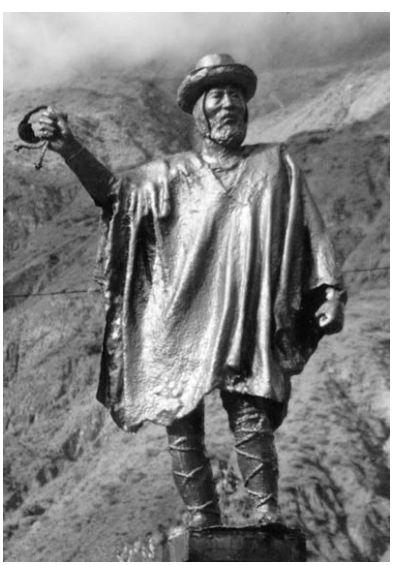
acciones militares: Huanta, Matará, Piquimqchay, Rucumachay, Atunhuancay y Atuntocto. En Saqapampa vencieron y aniquilaron a las tropas es- 
pañolas, por lo que Carratalá en venganza, contra los Morochucos, ingreso a Cangallo e hizo actos de bandidaje contra la población. Posteriormente las fuerzas de Basilio, vencieron nuevamente a los invasores en Chuschi. Auqui tuvo su centro de operaciones en Quijillapite, allí fue traicionado por uno de los naturales para cobrar la recompensa que por él se ofrecía. Capturado junto a su mujer e hijos fueron fusilados en febrero de 1822, a los 75 años de edad (Coronado 2006: 62).

Los Morochucos. Desde 1814, los Morochucos se mantuvieron en completa rebeldía contra el poder hispano, mereciendo que los realistas les aplicaran los epítetos de "criminales», "obcecados», "temerarios", etc. Desarrollaron sus acciones desde Huamanga hasta Ica y Huancayo, la causa patriota estaba ardiente entre ellos, hostilizaban en todas formas al enemigo, creándoles problemas y hostilizando sus comunicaciones. El coronel realista García Camba en sus Memorias relata: «La utilidad de la sumisión de los tenaces Morochucos, era fácil de comprender, atendiendo a que el ejército recibía todos sus recursos de las provincias de retaguardia; y el partido de Cangallo, población conocidamente valerosa, estaba sobre el camino real de Huamanga al Cusco, circunstancia que obligaba a emplear proporcionadas escoltas hasta para la conducción de un simple correo» (López Martínez 1974: 50).

En 1821, para superar estas dificultades, el virrey La Serna y Canterac acordaron enviar un ejército que diese buena cuenta de ellos. Al mando estuvo el diabólico José Carratalá, quien inició una verdadera guerra de exterminio que culminó con la total destrucción de Cangallo y con la muerte de miles de Morochucos (Ídem).

José Olaya Balandra, nació en Chorrillos en 1782, en la lucha por la Independencia del Perú, el prócer fue un emisario secreto llevando mensajes a nado, entre el gobierno del Callao y los patriotas de Lima. Este pescador de oficio fue el nexo entre las naves de la Escuadra Libertadora y los soldados de las fuerzas patriotas (argentinos, chilenos y peruanos) ubicadas en Lima. Nadaba de un punto a otro.

$\mathrm{Al}$ ser apresado por el ejército realista, lo torturaron con el fin de obtener información sobre las fuerzas patriotas. Descubierto, fue apresado y sometido a torturas que la historia detalla con precisión y condenado a muerte. Dice la historia que a pesar de las torturas, nunca reveló su misión y prefirió tragarse las cartas encomendadas para la misión. Según los historiadores, sufrió doscientos palazos y doscientos latigazos, le arrancaron las uñas, fue detenido mientras llevaba una carta del general Antonio José de Sucre para el patriota Narciso de la Colina. Lo capturó el español Ramón Rodil.

La mañana del 29 de junio de 1823, antes de ser fusilado en la Plaza Mayor de Lima, hoy Pasaje Olaya, dijo su frase que todos debemos recordar y practicar: "Si mil vidas tuviera gustoso las daría por mi patria». Sus familiares y los peruanos sentimos orgullo al recordar su nombre y acciones, lo consideramos como un héroe nacional (Perú 21, 20/06/2016).

Cayetano Quirós (el más grande jefe montonero). Según el mariscal Guillermo Miller, la partida de Cayetano Quirós era la más atrevida y la más temible de las montoneras. Los definió como hombres barbudos, grotescamente vestidos por amor a la patria, vertían su sangre y perdían su vida. Los jefes chapetones duplicaban sus tropas y destacamentos por temor a Quirós y su montonera. Mestizo, alto, fornido, simpático de rostro y bien compartido de cuerpo, de ojo vivo y penetrante, mirada altiva y audaz, era osado como pocos, astuto y sagaz, de gran carácter, un tipo romántico, por eso muy amado por quienes lo seguían en su montonero y al mismo tiempo muy respetado, obedecido y hasta temido. De origen oscuro y hasta ímprobo, el patriotismo lo convirtió en héroe. Cierta vez fue implicado en un robo. Aprehendido y sometido a juicio se fingió loco, hizo tan bien su papel que ni siquiera los facultativos que lo examinaban pudieron determinar si su locura era verdadera o falsa. El astuto juez introdujo a su mujer a la celda pero no la dejó disimular, porque sospechaba que era una trampa. No pudiendo resistir más las angustias y lágrimas de su mujer, le habló a esta la verdad y se descubrió. El juicio fue seguido y terminado, pero Quirós logró fugarse de la prisión.

Llegó al cuartel de San Martín guiando a fuerzas que decidieron pasarse a las fuerzas patriotas. Le contó al general su vida completa ofreciéndole una conversión, le pidió armas para cien guerrilleros, obtuvo la mitad y a los dos meses, tenía una partida de montoneros de doscientos hombres, bien armados y 
montados. Su primera gran hazaña fue la sorpresa de San Jerónimo de Huarochirí, donde el 12 de agosto de 1821 aniquiló un destacamento español que acababa de reducir a cenizas seis caseríos de la zona.

En la emboscada de Quillapata, en marzo de 1821 después de la acción destructiva en Concepción, los jefes espańoles Valdez y Ricafort decidieron regresar a Lima por Canta, en Ataura los indígenas mal armados y peor organizados sufrieron una carnicería feroz, unos 400 murieron en el choque y otro tanto en la mortífera persecución. Los montoneros enterados de la carnicería hecha en Huamanga, Cangallo, Ataura y otros lugares, convergían con gritos de venganza y castigo por la zona de Canta, ruta de descenso escogida por los realistas a la costa. Hacia allí también fueron con sus hombres, los jefes montoneros: Francisco Vivas, José Navajas, Alejandro Huavique, Francisco Vidal y Antonio Elguera, todos al mando de Cayetano Quirós. Esta vez los españoles se la verían con tropas, sino regulares, sí con jefes únicos, organizados, aguerridos y sobre todo provistos de armas tan modernas como las suyas (Coronado 2006: 49).

Confiados bajaban a Lima los realistas, por el ineludible paso del pueblo de Quillapata (Obrajillo), ignoraban totalmente un inusitado movimiento que bullía en las alturas, faldas y laderas de los cerros. Imperceptibles eran las voces de mando e incomprensibles los silbidos que rasgaban el aire. Hombres cobrizos de raza autóctona, negros y hasta blancos, todos con ponchos, iban y venían para ubicarse en el lugar previsto. A las ocho de la mañana del 2 de mayo de 1821, montan sus caballos los jefes de escuadrones y atienden las órdenes del caudillo general, Cayetano Quirós. A una señal de él sueltan terribles descargas de fusilería, llueven peñascos sobre el camino de Quillapata; los soldados realistas caen muertos unos sobre otros, caen también muchos heridos. Reina el desorden, la confusión y el pánico entre los soldados realistas. No pueden avanzar por el fuego de los bravos de Quirós, tampoco pueden retroceder por el mismo motivo, y por los flancos también les llueven balas y piedras. Cae herido el jefe del Estado Mayor, Vicente Guarín, el brigadier Ricafort se desploma con la pelvis atravesada por una bala, pero sus subalternos pueden montarlo y llevarlo a Canta. Un oficial y 90 soldados realistas yacen exánimes, otros se ahogan al tratar de cruzar el río Chillón, los heridos son innumerables. La Compañía Imperial Alejandro es hecha prisionera con su jefe, Juan Garrido. El triunfo patriota es completo. Si no aniquilaron a los realistas fue porque se acabaron las municiones. Ricafort esperaba con impaciencia a los 600 refuerzos solicitados a Lima. La emboscada de Huampaní fue otra acción bélica y un duro golpe a Rodil cuando se retiraba al Centro por el valle del Rímac, no pudieron eludir a los fieros montoneros que por sus espías sabían todos sus movimientos, pues los seguían sin perderle el paso. Al pasar por el fundo Huampaní, Cayetano Quirós y sus montoneros salieron de sus escondites, descolgáronse a bala limpia sobre la vanguardia, los flancos y la retaguardia de los realistas, el desorden y la dispersión de los virreinales es controlado por Rodil y Valdés. Ricafort estaba en camilla, logran reagrupar a sus fuerzas y, empeñándose en el combate les permite evitar la derrota (Coronado 2006: 59).

Su retirada hacia Ica e infortunio, un ataque de los morochucos a Carratalá, permite a Quirós y sus montoneras trasladarse hacia el sur, en Paras (26 abril) fue sorprendido por Ramón Rodil. Pelearon como leones los montoneros pero no pudieron evitar la derrota. La esposa de Quirós murió luchando, con ese doble revés la muerte de su esposa y la derrota, con unos cuantos guerrilleros siguió directo hacia Ica. Cuando se aproximaba a esta ciudad se encuentra con Carratalá, quien ordenó la muerte de María Parado de Bellido, éste puso sus terribles garras sobre Quirós y su disminuida montonera, corrieron diversa suerte los patriotas, muertos en combate la mayoría, otros fusilados o prisioneros. Unos cuantos fugitivos entre ellos Mariano y Tomás Bellido (esposo e hijo de María Parado), Cayetano Quirós logró huir una vez más.

Carratalá volvió a Ica, Raulet - patriota - tuvo que salir y ubicarse entre Pisco y Cañete, el realista lo siguió y derrotó. Se retiró al norte. Por coincidencia Quirós salió a la Puntilla, y se encontró con el ejército realista al mando de Villagra, intentaron batirse pero fueron acorralados por todas partes y hechos prisioneros. Fueron llevados a Ica y a la mańana siguiente, 5 de mayo 1822, el patriota Cayetano Quirós y sus hermanos de gloria e infortunio fueron fusilados en la plaza principal de Ica, con cartelones en la espalda que exponían la causa de su ejecución: «Por infame, bandoleros y asesinos... " (de Gamero, citado por Coronado: 61). 


\section{Bibliografía}

Aguirre Cárdenas, Max; Obregón Abilio, Mendoza Julio y CÁrdenas Jorge (2014). Primera Jura de la Independencia Peruana en Cangallo. S/e, Comisión de evocación histórica.

Bonilla, Heraclio (2010). Metáfora y realidad de la Independencia en el Perú. Lima: Fondo editorial Pedagógico San Marcos.

Bonilla, Heraclio (2010). Indios, negros y mestizos en la Independencia. Universidad Nacional de Colombia. Bogotá: Planeta.

Casana, Teodoro (1938). Homenaje Patriótico, artículo de Zavala Flores. E.F. : 97 a 105. Lima.

Congresos Internacionales. Hacia el Bicentenario de la Independencia. II, III, IV y V (2012, 13, 14,15). Vicerrectorado de Investigación, UNMSM. Tomos. I, II, III, IV. 2013 al16). Lima. Fondo Editorial

Coronado Ezquibal, Juan. (2006) Historia de los montoneros en el proceso de la Independencia del Perú. Lima: Ed. Juan Gutemberg.

Espinoza Soriano, Waldemar (1997). Virreinato del Perú. Lima: Biblioteca Nacional del Perú.

Espinoza Soriano, Waldemar (2016). Comentario analítico y crítico. Bicentenario de la independencia política de los criollos del Perú. En Hacia el bicentenario de la independencia. Lima: VRI-Fondo editorial UNMSM.

García, Manuel Andrés (2007). De peruanos e indios. La figura del indigena en la intelectualidad y politicas criollas (Perú: siglos XVIII-XIX). Espańa: Universidad de Andalucía.
López Martínez, Héctor (1974). Guerrillas y montoneras de la Emancipación en la Historiografía peruana. En la Comisión Nacional del Sesquicentenario de Independencia del Perú. Tercer Ciclo, La Indepencencia NacionaL. Editorial Jurídica S.A. Lima.

León Gonzales, Jesús A. (2018). Participación de Concepción en la Independencia del Perú. Huancayo: Taller Gráfico Servicios Múltiples.

Macera Dall'Orso, Pablo (1985). Historia del Perú 3. Independencia y República. Lima: Editorial Bruño.

MaYta, Apolinario y Canchari Miriam (2018). Junín rumbo al Bicentenario de la Independencia. Huancayo: Gobierno Regional de Junín.

Mendoza Villanueva, Pío (2012). Pasco en la Guerra de la Independencia. Industrias Nieto, Chamorro.

Quiroz Chueca, Francisco (2016). Regiones, tiempo e independencia en los Andes. En Hacia el bicentenario de la independencia. Lima: VRI-Fondo editorial UNMSM.

Rivera Serna, Raúl (1958). Los guerrilleros del Centro en la Emancipación peruana. Lima: Talleres gráficos Villanueva.

Ruiz, Milciades (Julio 20, 2018). Para meditar en «Fiestas Patrias». https://republicaequitativa.wordpress.com/).

Temple, Ella Dunbar (1971). La Revolución de Huánuco, Panatahuas y Huamalíes de 1812. Volúmenes I, II, III. Conspiraciones y Rebeliones en el siglo XIX, en la Colección Documental, Tomo III, publicado por La Comisión Nacional de Sesquicentenario de la Independencia del Perú. Lima. 